\title{
PERSISTENT ISSUES IMPACTING ON THE TRAINING OF MINISTERS IN THE SOUTH AFRICAN CONTEXT
}

\author{
Marilyn Naidoo \\ Department of Philosophy, Systematic and Practical Theology \\ University of South Africa
}

\begin{abstract}
In the midst of a changing landscape for higher education there is once more the question of vision and purpose of theological education. To what end should theological education be undertaken in South Africa to 'equip people for ministry'? The time of theological training is crucial for ministers to encourage a mature development of occupational and personal identity and foster a coherent understanding of their role and function in ministry. Ministerial formation must involve training and equipping pastoral leaders to do theology by involvement at a grassroots level and developing responsiveness to historical, biblical and pastoral dimensions within its context in order to have relevance. This article will present persistent issues facing ministerial formation in South Africa, focusing on the changing landscape of theological education, pedagogical and methodological challenges within the curriculum and the necessary support structures that make for relevant theological education.
\end{abstract}

Key Words:Ministerial Formation; Theological Education; Contextual Education; Theological Institutions

\section{Introduction}

Theological education and ministerial formation have been in a state of flux and uncertainty globally for a number of years. Seminaries, perturbed about economic survival, seek to retain current church constituencies while also trying to attract new markets (Warford 2007:31). Many institutions desiring to meet what are perceived as the current needs of the Church and society have spawned a variety of emphases and new degree programmes, formed partnerships and established institutes to do what the traditional curriculum seemed unable to do. Churches, frustrated with the graduates of theological schools, are challenging existing systems and joining their efforts to find a new model (Cannell 2006:36). In spite of these efforts, many graduates still struggle in ministry, many theological institutions still worry they may not survive and many churches continue to experiment with alternatives. Whether in crisis or merely in painful transition, the fact is that many churches, Christian groupings and theological institutions are engaging in a radical review of their theological education and ministerial formation programmes. This has been precipitated by the impact of globalisation on theological education, the process of rationalisation within educational and ecclesiastical institutions, the competing and sometimes adversarial interests of liberal, radical and conservative theological establishments and the crisis in the vocation with regard to the ordained and lay ministry within the Church (Percy 2010:138).

A key indicator of the character of today's Christianity is ministerial formation - it is precisely because of how Christian traditions recruit, train, equip and morally 'form' their 
leadership candidates which may determine the quality and faithfulness towards their calling in Christian ministry. Calling or vocation is exhibited in the character of the person in community, in concrete participation in the lives of people and a consistent message that heals, nurtures and matures the members of the community. Thus, the character, activities and teaching of ministerial candidates are crucial. Learning to be a minister encompasses the holistic development of individuals rather than being limited to either the acquisition of knowledge about the faith or even knowing how to behave as a minister (Scalise 2003). The acquisition of knowledge is essential in ministerial formation, but the scope of education must go beyond a restrictive cognitive qualification to more integrated human development. Theological education also requires a personal commitment and engagement, including a solid identification with the community.

Many schools of theology are again envisioning theological education as a formational activity; an activity based on the assumption that the student's personal appropriation of theology is the most central aspect of theological education (Foster, Dahill, Goleman \& Barbara 2006). Theological education then becomes an instrument of a broad-based formation process that ensures that ministerial candidates are properly 'formed' so that they can serve as the vanguard for the transmission and survival of a particular Christian tradition.

This article will present persistent issues challenging ministerial formation in South Africa focusing on three realities: the way theological education is structured; pedagogical challenges experienced within the curriculum; and the necessary support structures that impact on ministerial formation. Before observations are made about our South African context, it is necessary to make a few general remarks relating to ministerial formation in our broader context and the bearing this has on the kind of preparation for ministry for which theological institutions are inherently responsible.

\section{Realities of Theological Education in an African Context}

There has been a dramatic increase in demand for general higher education due to a younger and dynamic population in Africa, which is also reflected in a growing demand for theological education. The growth of the Church in Africa has been so enormous ${ }^{1}$ that the need for leaders far outstrips the ability of Bible and theological institutions, seminaries and correspondence programmes to supply them (Werner 2010:276). The models of ministerial formation in Africa are many and varied - denominational seminaries, public universities, apprenticeships, unaccredited Bible schools, short-term courses offered by well-meaning global partners, outright sale of certificates and a host of other strategies. More recently the new entrepreneurial concept of education in the Christian university has emerged with no clear line between theological and developmental agendas (Carpenter 2008:155).

In our African context the prevailing paradigm of theological education and even current proposals for its reform, exist within a Western frame of reference, which is fundamentally flawed (Mugambi 1995:3). While the Church is growing most rapidly in the South $^{2}$ most theological reflection remains captive to a Western model of theologising, reflecting the tension between African communal culture and the tendencies to isolation,

Cephas Omenyo (2002) states that there has been an insurgence of new formation patterns by evangelicals and Pentecostal/Charismatic groups and a 'charismatisation' of mainline churches in Ghana.

2 See “Tracking Global Christianity’s Statistical Centre of Gravity, AS 33-AD2100” (Johnson and Chung, 2004). 
individualism, and competition characteristic of Western culture. The Christian diet in Africa has been pre-packed theologies, ethical systems and pastoral methods, all imported from the West (Mugambi 1995:8). Sound intercultural relations leading to the indigenisation of the Christian faith is lacking in Africa (Richardson 2007). The sheer multiplicity of languages and cultures in the region makes church life and education a challenge. Culturally and linguistically appropriate programmes and resources for theological education are needed urgently. Also, the fact that in South Africa the Church and theology were embroiled in the struggle both for and against colonialism and apartheid has created a rocky road for indigenisation. According to Amanze (2009:121), traditional theology that has dominated the Church since the colonial period has proved inadequate to address the political, cultural, social, religious and economic issues facing African people today. He sees the pressing issues facing theological education as: (1) the need to take African culture seriously; (2) the demand made by women in church and society for equal opportunity in the ministry of the Church; (3) the need for churches to be involved in socioeconomic development; (4) the need of the Church to play an active role in the fight against HIV and AIDS; and (5) the need to develop a theology of liberation for those who are oppressed (Amanze 2009:122).

In South Africa, which is undergoing rapid economic and social change, theological education has already had to face significant developments. Ours is a context of different realities, one which is full of contradictions at the level of race, class and gender. The rich history of denominational theological education needs to be understood in relation to a matrix of factors that together contribute to the problems that challenge contemporary ministerial formation in South Africa. In the midst of a changing landscape for higher education there is once more the question of vision and purpose of theological education. To what end should theological education be undertaken in South Africa to 'equip people for ministry'? What view of the present and the future needs to drive it, to situate it historically and practically in the challenges facing the Church and its ministry now? Such questions require some basic analysis of our condition.

\section{Implications of Higher Education Changes}

It is important to note four distinctive eras of theological education and ministerial training (Richardson 2007:132) and to recognise the changing cultural and political contexts within which the successive eras developed in South Africa. The first (1867-1948) was the missionary era which was characterised by two main interfaces, that of Western Christianity and Africa, and the interface of power between British colonial authority and the loss of African autonomy. The second era (1948-1990) saw the imposition of the notoriously oppressive political system know as apartheid. Overlapping with apartheid was the third era (1960-1990), that of resistance against apartheid particularly in the case of the churches that participated in ecumenical initiatives and structures such as the South Africa Council of Churches. Finally, there is the emerging post-apartheid era (1994 to the present) in which the churches are trying to make sense of their new role in terms of culture, political profile and social influence.

In South Africa, due to the restructuring of higher education over the past decade, theological faculties at public universities across the country, with very few exceptions, have shrunk significantly, if they have not disappeared. Many factors have contributed to this crisis in theological education and Richardson (2007) lists the following as some of them: (a) changes in the funding bases, both state and international donors; (b) national 
curriculum and education policy changes at secondary school level; (c) the demise of ecumenism and a return to denominationalism; and (d) the subsequent threat of closure to a number of theological faculties. Some universities moved from Christian theological training to a more general study of religion. Programme rationalisation to increase efficiency and to harmonise curricula, also led to fewer theological courses at some institutions.

Formal theological education in South Africa has come under severe pressure as a consequence of increased costs of residential training in relation to the financial capacity of churches. Mainline churches found it increasingly difficult to cover expenses and to keep programmes running due to shrinking church membership and fewer ministerial candidates. The increased levels of institutional change created instability from which institutions are only now recovering. Each institution's struggle with identity - the definition and purpose and mission, the creation and abandonment of programmes and the search for fiscal stability - profoundly affected the practice of teaching and learning. While restructuring and closure have been some of the responses to the crisis, another significant response has been to force a financial review of theological education. Many seminaries and Bible colleges, as a response to the crisis, have found 'partners', especially among universities. The positive effect of these movements is, hopefully, stronger ecumenical co-operation among the various churches that have collaborated. However, some have legitimate fears that the wheeling-and-dealing has lead to a 'lowering of standards' in theological education (Maluleke 1998:14).

Instability in theological education was hugely aggravated by the issue of accreditation and quality assurance. With the arrival of democracy in 1994 and the emergence of a new education system, the issue of accreditation and quality assurance began to surface as extremely important. Higher education systems have previously been characterised by fragmentation, uneven provision and decades of racial segregation. The challenge of higher education transformation co-existed with demands for social and economic justice that was at the core of the agenda of democratic change in South African society (Levy 2007:205). New institutions and mechanisms were put in place to deal with accreditation and authorisation such as the South African Qualifications Authority (SAQA) with its National Qualifications Framework. On the one hand legislation created new opportunities for private providers to offer degrees, but on the other hand it imposed stringent requirements on providers outside the public system. These have included compliance with curriculum parameters laid down in the new national education policy, as well as structural and institutional requirements relating to governance and quality assurance. Non-compliance carries the real threat of the refusal of registration and enforced closure. This new system did not provide for any accrediting bodies other than itself. Therefore the church-initiated Joint Board for the Theology Diploma was no longer recognised and could, consequently, no longer accredit the work conducted in seminaries. ${ }^{3}$

A common diploma was awarded to students of colleges that operated under the Joint Board, with quality assurance being provided by the Board. Each of the nineteen seminaries previously accredited with the Joint Board had to apply for accreditation, an expensive exercise which many found difficult (Richardson 2007:145), and which resulted in

In 1965 participating churches (Anglican, Methodist, Congregational Church) together established the Joint Board for the Diploma in Theology set up by the South African Council for Theological Education (SACTE) which included representation from across mainline denominations in Southern Africa; it became the chief accrediting body until the new South African educational legislation (in Richardson 2007:144). 
denominational seminaries losing new students to other institutions, as seen in the case of the Anglican and Methodist seminaries (Naidoo 2012b). The new scramble for accreditation was initially an unsettling adjustment for many because of its technical nature. Institutions had to register with the national Department of Education (DoE), be accredited by the Council for Higher Education (CHE) and have their courses accepted and registered with SAQA. However, positively, accreditation forces theological institutions to be accountable to government and accrediting agencies, the Church and the general public and this could result in greater effectiveness.

The new OBE curriculum features specific outcomes, the assessment of criteria and range statements which specify how those outcomes should be achieved. The initial design of the curriculum was grounded in two concerns: education should be contextual and learners should possess usable knowledge. The concern for theological education was that the exaggerated focus on 'knowledge' was elevated to the status of sacred text, to be transmitted, memorized and perhaps contemplated but not used. This led to a deep identity crisis not only for theologians, but also for those involved in the human and social sciences, because now teaching was more about the production of knowledge. Theological institutions also had to resolve the tension between the status of institution as autonomous authority with statutory recognition and as serving local Christian communities and churches (Moodie 2008:61).

The increasing demand for theological education in South Africa has given rise to a mushrooming of new colleges and Bible schools which has, in turn, created tensions between public and private providers of theological education as they compete for students. The sudden growth in private theological education was partly because some people wished to retain specific identities and values that they perceived to be under threat (Levy 2007:205). At the same time some church traditions have established their own ministerial training rather than looking to the traditional theological college or university, as evident from the Charismatic network (Neumann 2012). While it may be argued that most churches are not in a position to provide theological education at an appropriate post secondary level, this developing pattern does demonstrate that the needs of the Church have changed and may require different types of training.

A newer development has been the internationalisation of theological education (Nysse 2011). This internationalisation trend refers to the growth of international students and faculty and extends well beyond the mobility of people to the movement of institutions. Higher education is now being exported from one country to another, particularly from the United States. Extension centres, branch campuses, franchising operations, and various other 'transnational' higher education arrangements have become commonplace. For example, much of what is happening in and through the rapid spread of evangelical or Pentecostal theological education is reflected in the shortage of uncontextualised teaching material and curriculum plans (Werner 2010). The demand for flexibility of delivery has also led to another form of internationalisation, characterised by moving content, knowledge, and courseware across borders.

In spite of the widening digital or knowledge divide in South Africa there is a surge of interest in new technologies which is causing an eager population to become further connected, though still to varying degrees. Open Distance Learning (ODL) is a growing option for theological education which focuses on flexibility of learning provision, studentcentredness and constructing learning programmes with the expectation that students can 
succeed. In spite of the costs of infrastructure development, ODL has become an option for a growing number of South African universities. ${ }^{4}$

Advances in technology, the demands of an increasingly mobile and diverse population, economic realities, the emphasis on the democratisation of education and dissatisfaction with traditional models are some of the issues that are sparking renewed interest in online and distance theological education. More research still needs to be done on how theological training institutions should make proper use of modern communication and information technologies for theological teaching. It has freed students from the constraints of time and space, but it has also created a new set of challenges in terms of ministerial formation (Naidoo 2012a).

\section{Need for Curriculum Reform}

A recurring theme in theological education is the need for curricular and methodology changes within the curriculum. The history of theological education in this region has been characterised basically by foreignness, that is, foreign theological content, methodology and languages. In recent years theological educators have realised the need to take African culture seriously in order to produce a relevant theology for the African people (Bediako 1984; Tienou 1984). John Pobee notes that "the task is to develop an authentically African expression of the one gospel... expressing the one gospel in such a way that not only will Africans see and understand it but also non-Africans will see themselves as sharing a common heritage with Africans” (1996:49). The idea is that the Church needs to become African in belief, theology and practice for it to be truly African (Maluleke 1996). Bediako notes that this search actually constituted a new theological methodology, the 'hermeneutic of identity' (1984:16), not sourced in a Western dominated model of theological engagement, but in a genuinely biblical encounter with their religious past. It begins when theological education develops contextual approaches and hermeneutical methods like hermeneutics of inculturation or liberation (Kiogora 1998) based on the way African people conceive and interpret reality; Christianity based on spiritual worldviews, supernatural powers, pre-Enlightenment concepts and the importance of charismatic power or supernatural energies of the Holy Spirit.

By inverting the issue of identity Maluleke (1998:14) asks the question, "Would we like to know ourselves theologically, and how can there be Africanization if only one side is known and used? How can Africanization become a subconscious part of our theologizing?” By Africanisation Maluleke means more than just the teaching of or inclusion of black and African issues in curricula, but also the 'main-streaming' of African issues in theological education. For example, in South Africa the African Independent Churches (AICS) have resolved the dualism between Western-orientated Christianity and African traditional culture and religion, and have been successful in coming to grips with their identity. In affirming our African identity, we need to affirm indigenous theology and there needs to be a new dialogue with AICS who provide a place to feel at home as African Christians. Or again, because of the multiplicity of languages and cultures in the region, cultural and vernacular programmes and resources for theological education are needed

In South Africa the bulk of distance education students are registered with the University of South Africa, with significant enrolments at the North-West University, Pretoria University, Stellenbosch University and the University of KwaZulu-Natal (SAIDE 2010). 
urgently. The University of South Africa has begun the multilingual Theological Dictionary Project which will translate key theological terms into South African languages.

Could it be that theological education and ministerial formation in Africa are irrelevant because theological articulations are based on a theology which is contextually Western but assumed to be universal? Any leadership needs to be an informed leadership; it is incongruous to have Western intellectual and theological leadership of a non-western Church. Hence there must be a rediscovery, appreciation and mature re-appropriation (Maluleke 1996:19) of inherent traditional African values and responses towards education.

It is impossible to talk about renewal in theological education, particularly in our part of the world, without addressing the issue of contextualisation (Haleblian 1983:97). African theologians serving in church leadership roles, along with missiologists, have been at the forefront of those tending to focus on African culture as a whole, not just on African religion, reflecting theologically on the necessary contextualisation of Christianity within African culture. Catholic reflection has vigorously debated whether adaptation or incarnation is the more appropriate theological methodology, while one strand of Catholic reflection has also probed into the underlying world views or 'implicit philosophies' of traditional Africa (Bowers 2002). Protestant reflection has often led the way in looking for points of contact between standard themes of Christian theology (such as revelation, sin, Christology or eschatology) and those values, institutions, concepts and symbols which underlie African culture (Bowers 2002). Church leadership participating in theological discussion tends to frame its reflection much more directly in terms of the pastoral and catechetical needs of the believing Christian community in Africa, especially as it is affected by traditional culture, for example, with respect to rites of passage, polygamy, liturgical custom, divination, traditional healing or the role of ancestors.

In South Africa the Institute for Contextual Theology (ICT) was founded in 1980 "to develop a truly South Africa theology... not imported either from Europe or USA or Latin America, a theology which starts from our situation of oppression and conflict” (Nolan 1991:235). This Institute assisted particular denominations among the African Initiated Churches to produce documents in which they spoke for themselves. The type of theologies that emerged through the facilitation of the ICT was of various kinds: black theology, feminist theology, youth theology, a workers' theology, a prophetic theology and a Kairos theology (Nolan 1991:235). The statements issued by evangelicals on Evangelical witness in South Africa and the Pentecostals on Relevant Pentecostal witness in the late 1980s, as well as the Confession of Belhar (1986) could be regarded as profound expressions of contextualisation (Botha 2010:185). A new round of contextual theologies, ${ }^{5}$ offered through Speckmann (2001), focused on the developmental dimensions in contextual theology and Van der Water (2001) focused on the legacy of prophetic theology as expounded in the Kairos document. Others have thought that the quest for reconciliation and healing in South Africa was a good source of contextual theology. Theology must create a critical awareness of the situations and must be present and involved in the lives of people and enter into dialogue with the reality of the situation. As Botha suggests, there needs to be a faith commitment to the struggles of the people, for example, in the issue of poverty, abuse of women and children, HIV/Aids, xenophobia, and a rigorous social,

For a fuller discussion see Nico Botha's article on contextual theology and contextualisation in South Africa (2010:181-195). 
cultural, historical, economic and political analysis within theological reflection and more action (Botha 2010:194).

At the same time there is a growing awareness of the need for spiritual formation programmes within theological education (Naidoo 2011). Those undertaking ordination training need to acquire the spiritual maturity to inhabit a complex and contested social and theological space with sensitivity and nuance. Central to the issues of training are those of role and ministerial identity, for if people have not come to terms with who they are as individuals, then no amount of preparation and training will help; instead it will underlie their inadequacy, ineffectiveness and incompetence and lack of proper place. A number of writers have highlighted that one of the primary weaknesses of theological education is the lack of training in terms of self-development (Francis \& Jones 1996; Warford 2007; Jones 2002). This concern appears to be evident in the observation of similar deficiencies in foundational relational abilities found amongst students entering seminary and that is prevalent among pastors (Hall 1997). An appropriate way to think of the involvement of the theological institution in ministerial education is not as preparatory, but as developmental (Cannell 2006:38). Since the curriculum is already hopelessly mired with courses, the curriculum could be configured to allow an appropriate sequence of courses, while other courses are removed from the curriculum, to become part of lifelong learning components of the graduate's experience. Professional education, except in ministerial education, presumes that the development of the professional capacity takes place over several years, that is, it does not end once a degree is in hand. Further, the continuance in the profession is contingent upon regular and continuing education where the individual interacts with other professional fields and is guided in reflection-on-practice. It would be better to strip the theological curriculum and surround the theological institution with institutes and nonformal experiences able to offer the best of professional development.

Shaping ministerial identity is one of the main reasons why pedagogies of formation need to play a significant role in theological education. A recent study on the intentionality of spiritual formation in theological education in South Africa found that theological institutions were committed to the spiritual development of students during their training for church leadership (Naidoo 2011). However, how that was implemented varied significantly. Other challenges for our context could include concerns of how to reconcile formation as a corporate term with the functional, individualistic cast of theological curricula and outcomes (Senior \& Weber 1994). Attempting formation in an intercultural community has its challenges of ethnocentrism and prejudice, and formation processes must take the personal and contextual into account with equal seriousness (Linder 1997).

Moral formation is an aspect of spiritual formation; spiritual maturity results in moral formation and committed discipleship. Disputes about the moral expectations attached to church leadership are not about what is permissible, but about what is exemplary (Neuhaus 1992:3). In situations where accountability, transparency and patterns of governance in church leadership are low, questions regularly arise such as: What is wrong with the theological education which church leaders receive when, later, pastors fall prey to corruption and the misuse of ministerial power, and are prone to violation of standards of responsibility and accountability of church ministry? While not all failures in leadership positions can be attributed to their theological training, it is still a valid question to explore whether more emphasis can be given in theological education curricula to character formation or a code of conduct for church leadership. It is necessary for the action of leaders to be tested against the moral paradigm they claim to be upholding, and the moral 
framework itself needs to be evaluated (Kretzschmar 1998). The quality of leaders developed at theological institutions must have consequences for the broader community. Kretzschmar (2006:349) asks the question: "Does the African church have the moral stature, spiritual discernment, managerial competence to contribute to the liberation and reconstruction of the continent?"

Theological education must have a critical-prophetical role to articulate the public role and responsibility of Christian witness in relation to current trends, challenges and shortcomings in society. The curriculum should adopt a more deliberate and conscious account of the socio-economic, cultural, political and spiritual contexts of the majority with the aim of transforming these contexts into worthy habitable spaces. The curriculum in our context has mostly followed the 'clerical paradigm' and prepared students to enter traditional church leadership roles, hence the challenge for theological education is to cultivate Christian leaders who can mobilize communities to be adaptive.

We observe that while the South African government have gender policies and have adopted quotas for women participating in decision making at the highest levels, theological institutions do not have clear gender policies. They do not have mechanisms of redressing historical injustices and cultural prejudices against women. Theologians are called upon to adopt liberative hermeneutical paradigms which will enable Christians to transcend the patriarchal domination. Theological education must be Africanized and feminized to overcome the androcentric aspects of both the African culture and the Christian religion (Gundani, Masenya, Maluleke \& Phiri 2002). In addition, there needs to be more training in the area of inter-religious dialogue and praxis. Many churches in South Africa are not open to ecumenical dialogue, not to speak of interfaith encounters. Students should be helped to reflect on their religious contexts and develop theologies that promote religious coexistence, freedom of conscience and respect for diversity. Also, there should be more reflection of our postmodern environment and the impact of a 'global' culture on African ways of being and the resultant plurality and cultural diversity in South Africa.

Theological educational exposure on an interdisciplinary level that is in contact with other models, traditions and faiths; self-criticism and planning; constant re-evaluation and the like, is imperative. Curriculum reform would require more than a simple re-clustering of subjects. It is concerned with the often un-reflected cultural, epistemological and denominational presuppositions and attitudes that are sustained. The implications of a changed view of truth, power, culture, God and gods and all other issues are seldom reckoned with in theological education.

\section{Educational Approach used in Training Ministers}

An important methodological issue that presents a challenge to ministerial training is the overly academic approach applied at South Africa universities. Since the time of Friedrich Schleiermacher many have espoused the notion that theological scholarship can be completely or largely detached from concerns related to the faith commitment of the theological student, which has forced the question, What is 'theological' about theological education? (Kelsey 1992). The goals of the traditional intellectual approach to the academic study of theology found in universities often omit personal formational elements, despite evidence that students in these courses often enrol for formational reasons (Graham 2002:230). How is the inner coherence and church-related responsibility of theological education exercised if the structural framework does not allow staff to emphasis ministerial formation? 
University education supports the development of a critical perspective in students, creating a commitment to the necessity of interrogating all religious knowledge to avoid distortion and to seek after the essence of faith. From such study students develop knowledge, understanding, vision and normative patterns which will guide them as church leaders. However, students experience fragmentation and wrestle with combining the academic and vocational perspectives. The teaching and learning process depends mostly on teachers' lectures in the classroom, consisting of a heavy workload, followed by assessment and examination that relies on memorisation, all fostering individualism and competition for grades. In addition, university faculties have become so diversified that theological disciplines are no longer able to converse meaningfully with one another. Each discipline has its own methodology and, hence, its own language; and because of this it loses its capacity to reflect on a common goal and concern, when contributing to forming effective ministers. Moreover, the openness of the curriculum itself aids the 'consumer mentality' of our culture, thus reinforcing the character and values of students and frustrating the theological faculty's attempt to become involved - if they so desire.

In spite of the developments towards a more holistic view of the individual learner in higher education, the dissonance between educational philosophy and theological understanding of the person and of formation would not seem to suggest that universities are an ideal partner in learning for ministry (Wilton 2007). Higher education develops individuals within a market context of competition, while the Church seeks to form individuals to inhabit theological understandings, involving an understanding of personhood in community (Overend 2007). Structural partnerships are generally difficult because of divergent institutional aims (Wilton 2007:158). An exception to the case in South Africa is the Reformed tradition that is connected to four historically white universities for the training of their ministers.

An alternative to the 'Berlin' approach to theological education is the 'Athens' approach (Kelsey 1993), which accentuates a movement from sources to personal appropriation of traditions and revealed wisdom in such a way that it forms identity and transforms persons and communities. It is a formational notion of theological education which Farley (1983:36-37) labels theologia, the unity and goal of which was the saving knowledge of God. In this approach the teacher shares his or her struggles to impart wisdom to the student. The most meaningful experiences for students are focused on the teacher's relational skills, personal qualities, and the in-class interactive teaching and learning methods (Foster et al. 2006). For students, developing community and relationships within an academic setting is not only important, but also necessary in facilitating learning. The goal is to help the student undergo a deep kind of formation, a personal appropriation of wisdom about God, self and the world where learning is not just a personal matter, but is for the sake of public life, ecclesial life and church leadership (Foster et al 2006). This is in line with what Groome refers to as reflective practitioners; 6 "they should be invited to discern and express their own critical understanding of both praxis and theory and be sponsored through judgment and decision to see for themselves and responsibly choose what is appropriate to lived Christian faith” (1989:71). In this way, Groome states, people do theology 'on their feet' rather than 'in their heads' (1989:71).

The reflective judgment literature and those concerned about praxis assert that theological education is a reflection on the practice of ministry while one is involved in that ministry. The assumption of a theory-to practice linearity is replaced with the assumption that practice can also influence theory (Cannell 2006:36). 


\section{Support of Theological Education in South Africa}

Relevant pastoral leadership can be best produced by developing a closer partnership between the theological institution and the Church so that students can learn first-hand from churches how communities work. However, the Church is sometimes a distant partner in the preparation of candidates for ministry. Some of that distance results from the implicit trust of the denomination in the expertise of the theological institution or seminary. Some results from the seminary's reluctance to let the Church become too deeply involved in the functions of the seminary. A whole range of conflicts could arise between Church and theological institutions concerning the understanding of the Gospel, the mission of the Church, the nature of ministry, the role of specific ministries, etc. Theological differences on the liberal-conservative axis, missional mandates of social justice, evangelism, or both and even the quality of students delivered to the seminary for training could raise tension.

Theological institutions and churches have constantly faced the challenge of meeting each others' expectations. On the one hand, theological institutions expect churches to send the most qualified students, which include qualifications of dedication, academic competence and good character. On the other hand churches expect theological institutions to produce dynamic preachers with wholesome values who have both administrative and managerial as well as spiritual strengths and pastoral counselling skills. A creative tension exists here in many contexts. The precise form that this partnership takes will vary because the relationships between schools and churches differ so widely. In many institutions, theology is expected simply to confirm and to defend the teaching and positions held by the Church. Other schools consider theological thinking as an exercise which is to be carried out in complete independence of the Church. An example in terms of ministerial formation, in which the seminary and the Church can work closely together, is the development of the identity of a minister as pastoral leader. Church leaders and denominational officers need to understand the challenges of seminary formation in all its dimensions and the reasons that standards are often rigorous and demanding. At the same time, theological faculties need to be in intimate communication with denominational leaders, exemplary pastors and lay leaders about the life of the Church in the world.

For partnerships between the churches and academia to work - they are generally difficult because of divergent institutional aims - academia needs to recognise the distinction of the practitioner, otherwise this relationship will not be seen in Christian circles as a partnership of equals, where there is equal respect for one another's approaches to learning (Wilton 2007:45). What is needed is for denominations, through reviewers and inspectors, to conduct a theological audit of the ecclesial nature of the training institution and its students on the basis of benchmark statements true to its tradition, but also engaging with the wider Church's life and mission. An example of this is the Church of England report, Formation for Ministry within a Learning Church (The Hind Report, Archbishops' Council, 2003) in which an educational and assessment framework was developed for ministerial training. Accreditation bodies cannot be the only source for the assessment and accreditation of theological institutions. The Church will need to assist the theological institution in redefining the meaning of ministerial profession, the role of leadership and the educational formats that will serve the goals that emerge from these conversations.

An issue that is important in supporting ministerial training and formation is that of ecumenical commitment and involvement in South Africa. There is a resurgence of denominationalism in theological education, which is not a good sign for the integrity of Christian witness within the Protestant family (Naidoo 2012b). Many denominations, even 
smaller churches, tend to build or to plan their own theological colleges. The denominational fragmentation of theological education is one of the root causes for the continuation of the ecumenical divide. It is important to strengthen the denominational identity of future pastors so that graduates understand the tradition to which they belong but, on the other hand, it also remains an important task to introduce students to the wider horizons of the worldwide Church, to enable an understanding of what their membership means to the ecumenical fellowship of churches. It is vital for any theological education to prepare candidates to engage with models of church unity, to reflect theologically on 'unity in diversity' and to ask them to study how the relation between commitment to local and denominational identity and the ecumenical worldwide fellowship can be founded theologically and lived out in a sound manner.

A genuine ecumenical commitment will not only acknowledge the differences between churches, but will work towards their reconciliation. The Federal Theological Seminary of South Africa (Fedsem), founded and established in 1967, represented a shining example of ecumenical commitment and ministerial formation in southern Africa. In response to the exclusion of apartheid, a small number of the 'English speaking churches' ${ }^{7}$ in southern Africa, namely; the United Congregational Church of Southern Africa, the Presbyterian Group of Churches in Southern Africa, the Methodist Church of Southern Africa and the Church of the Province of South Africa rallied together and created an alternative to the government sponsored theological education facilities for blacks, coloureds and Asians. Unfortunately, ecumenical theological education in South Africa, which survived over four decades of apartheid, did not survive the decade of liberation (Richardson 2007:144). The anti-apartheid churches, which invested so much of their resources in the struggle, now seem to have lost their fervour for justice, their ecumenical spirit and their passion for rallying together against a common enemy (Denis 2003). Indeed, these churches are still struggling to find the new trends of a common and unifying vision. However, it has been encouraging to read new signs of hope as denominations, namely the Presbyterians, Methodists and the Lutherans again embody ecumenical principles through the sharing of resources, through the establishment of ecumenical relationships, courses and the interchange of faculty and students of different traditions.

At the same time, we are aware that the very contours of historic Christianity are changing as a result of the phenomenal growth of Pentecostal and independent churches (Werner 2009:38). Indeed, Christianity itself is far more variegated and divided today than at any time previously in its history. This has had an impact on theological education and other aspects of the life of the Church.

\section{Conclusion}

The above discussion has been a spread of pertinent issues on the way theological education is structured, the content and processors of the theological curriculum and the necessary support structures for theological education in South Africa. The task and challenge of transforming ministerial formation and theological education is an ongoing and dynamic one. The transformational strategies for formation, training and education of church leaders that will prevail are those that read the Church deeply. The challenge then is

The historical origin of this terrn in the southern African context is obscure. John de Gruchy suggests that the designation is one that was imposed by the 'mass media, politicians, other churches and the populace in general’ (The Church struggle in South Africa, Eerdmans, 1979:85). 
to engage in a rich and profound audit of the ecclesiology and praxis; to comprehend the real, raw church in all its complexity and work creatively from there (Percy 2010:124). If the broad ecclesial ecology is not understood at the outset, it will lead to frustration as visions, strategies and tactics continually fall short of their promised goals. This can lead to boredom, collusion and, eventually, the onset of deeply embedded cynicism.

A stress on formation is not going to be some kind of 'magic bullet'. Western suggests that ministerial formation will be achieved "through a process of collective and individual formation rather than an ad hoc set of developmental opportunities and experiences" (2008:202). Ministerial formation needs to hold the whole institutional environment in mind, and needs to take a holistic view to create a consistent context for learning. Ideally, a model for ministerial formation is one that has an integrated and ecclesial approach, focused on the theological institution as an educational community led by faithful and exemplary teachers who retain a focus on habitus (Farley 1983) as theological method for formation. To do this, ministerial formation needs to become more intentional within the curriculum and influence the content, method and outcomes of theological education. It ought to include constructive 'formative' experiences that open up the tradition to students in ways they have not previously attained. This requires particular gifts on the part of faculty and particular insights about teaching and learning and a supportive environment. When multiple methods, which are congruent with contextual realities, are aligned in an intentional way, the effect will be powerful.

\section{BIBLIOGRAPHY}

Amanze, J 2009. Paradigm shift in theological education in southern and central Africa and its relevance to ministerial formation. International Review of Mission 98:120-131.

Archbishop's Council 2003. Formation for ministry within a learning Church (The Hind Report). London: Church House Publishing.

Bediako, K 1984. Biblical Christologies in the context of African traditional religions, in Sharing Jesus in the Two Thirds World: Evangelical Christologies from the context of poverty, powerlessness and religious pluralism edited by Vinay Samuel and Chris Sugden. Grand Rapids: Eerdmans.

Botha, N 2010. If everything is contextualization, nothing is contextualization: historical, methodological and epistemological perspectives. Missionalia 38(2):181-196.

Bowers, P 2002. African theology: its history, dynamics, scope and future. Africa Journal of Evangelical Theology 21(2):109-125.

Cannell, L 2006. Theological education matters - Leadership education for the Church. Newburgh, IN: Edcot Press.

Carpenter, J 2008. New Evangelical Universities: Cogs in a World System or Players, in Interpreting Contemporary Christianity edited by Ogbu U Kalu and Alaine Low. Cambridge: Eerdmans, 151-186.

De Gruchy, J 1979. The church struggle in South Africa. Grand Rapids: Eerdmans.

Denis, P 2003. Fedsem ten years later: the unwritten history of an ecumenical seminary. Journal of Theology for Southern Africa, 117:68-79.

Farley, E 1983.Theologia: the fragmentation and unity of theological education. Philadelphia: Fortress Press. 
Foster, C, Dahill, LE, Golemon, LA \& Barbara, WT 2006. Educating clergy: teaching practices and pastoral imaginations. San Francisco: Jossey Bass.

Francis, L \& Jones, SH 1996. Psychological perspectives on Christian ministry. Leominster: Gracewing.

Graham, SL 2002. Theological education on the web: a case study in formation for ministry. Teaching Theology and Religion 5(4):227-235.

Groome, T 1989. A religious educator's response, in The education of the practical theologian: response to Joseph Hough and John Cobb's Christian identity and theological education edited by Don Browning, David Polk and Ian Evison. Atlanta: Scholars Press: 77-91.

Gundani, PH, Masenya, M, Maluleke, TS \& Phiri, I 2002. The state of theological education in Southern Africa: Issues and Concerns. Ministerial Formation July/Oct:66-73.

Haleblian, K 1983. The problem of contextualization. Missiology: An International Review. XI(1):95-107.

Hall, T 1997. The personal functioning of pastors: a review of empirical research with implications for the care of pastors. Journal of Psychology and Theology 25:240-253.

Johnson,TM \& Sun Young Chung 2009. Tracking Global Christianity’s Statistical Centre of Gravity, AD 33-AD 2100. International Review of Mission 93 (369):166-181.

Jones, GL 2002. Beliefs, desires, practices and the end of theological education, in Practicing theology: beliefs and practices in Christian life, edited by Miroslav Volf and Dorothy Bass. Grand Rapids, MI: Eerdmans.

Kelsey, DH 1992. To understand God truly: what's theological about a theological school. Louisville, Ky: Westminster John Knox Press.

Kelsey, DH 1993. Between Athens and Berlin: the theological education debate. Grand Rapids, Mich: Eerdmans.

Kiogora, TG 1998. Black Hermeneutics, in Initiation into theology: the rich variety of theology and hermeneutics by Simon Maimela and Adrio Konig. Pretoria: Van Schaik: 337-349.

Kretschmar, L 2006. The indispensability of spiritual formation for Christian leaders. Missionalia 34; 2(3):338-361.

Kretschmar, L 1998. Evangelical spirituality: A South African perspective. Religion and Theology 5(2):154-175.

Levy, D 2007. A recent echo: African private higher education in an international Perspective. Journal of Higher Education in Africa 5:197-220.

Lindner, J 1997. Ecumenical formation: a methodology for a pluralistic age. Theological Education 34:7-4.

Lucas, D 1990. Leadership training in Sub-Saharan Africa. Christian Education Journal 10(3):91-107.

Maluleke, T 1996. African culture, African intellectuals and white academy in South Africa. Religion and Theology 3(1):19-42.

Maluleke, T 1998. Africanization, liberation \& transformation in Theological Education. Johannesburg: NICTE Publication. 
http://scriptura.journals.ac.za

Persistent Issues Impacting on the Training of Ministers in the South African Context 15

Moodie, T 2008. TEE College of South Africa, in Diversified Theological Education:

Equipping all God's people, edited by R Kinsler. Pasenda: William Carey International University:47-80.

Mugambi, JNK 1995. From liberation to reconstruction: African Christian theology after the Cold War. Nairobi: East African Educational Publishers.

Naidoo, M 2011. An empirical study on spiritual formation at theological training institutions in South AfricaReligion and Theology 18(4):118-146.

Naidoo, M 2012a. Ministerial formation of theological students through distance education. HTS Theological Studies 68:1-8.

Naidoo, M 2012b (ed.). Between the real and the ideal: ministerial formation in South African churches. Pretoria: Unisa Press.

Neuhaus, RJ 1992. Theological Education and moral formation. Grand Rapids, Mich: Eerdmans.

Neumann, M 2012. Ministerial formation in Charismatic context: heads, hearts and hands, in Between the Real and the Ideal: Ministerial Formation in South African Churches, edited by M Naidoo. Pretoria: Unisa Press: 133-146.

Nolan, A 1991. Doing theology in the South African context in Trends in mission toward the third millennium, edited byWilliam Jenkinson and Helen O'Sullivan. Maryknoll: Orbis Books.

Nysse, R 2011. Learning from “digital natives:” forming a new generation of religious Leaders. Reflective Practice: Formation and Supervision in Ministry 31:11-19.

Omenyo, C 2002. Pentecost outside Pentecostalism: a study of the development of Charismatic renewal in the mainline churches in Ghana. Zoetermeer: Uitgeverij Boekecentrum.

Overend, P 2007. Education or formation: the issue of personhood in learning for ministry. Journal of Adult Theological Education 4(2):133-148.

Pobee, J 1996. West Africa: Christ would be an African too. Geneva: WCC Publications.

Percy, M 2010. Shaping the church: the promise of implicit theology. Burlington: Ashgate.

Richardson, N 2007. Ministerial training and theological education in the Methodist Church of Southern Africa: the road ahead. Missionalia 35(2):131-152.

Scalise, C 2003. Bridging the gap: connecting what you learned in seminary with what you find in the congregation. Nashville, TN: Abingdon Press.

Senior, D \& Weber, T 1994. What is the character of curriculum, formation and cultivation of ministerial leadership in the good theological school? Theological Education XXX; 2:17-33.

South African Institute for Distance Education. Overview of Distance Education in South Africa. September 2010 (http://www.saide.org.za/DistanceEducation/tabid/1430/Default.aspx).

Speckman, M 2001. For Nolan's sake, let's move on: a plea for a developmental dimension in contextual theology, in Towards an agenda for contextual theology: essays in honour of Albert Nolan, edited by McGlory Speckman and Larry Kaufmann. Pietermaritzburg: Cluster Publications. 
Tienou, T 1984. The church in African theology: descriptions and analysis of hermeneutical presuppositions, in Biblical interpretation and the church: text and context, edited by Donald Arthur Carson. Exeter: The Paternoster Press.

Van der Water, D 2001. A legacy for contextual theology: prophetic theology and the challenge of the Kairos, in Towards an agenda for contextual theology: essays in honour of Albert Nolan, edited by McGlory Speckman and Larry Kaufmann. Pietermaritzburg: Cluster Publications.

Warford, M (ed.) 2007. Practical wisdom: on theological teaching and learning. New York: Peter Lang.

Werner, D 2010. Viability and ecumenical perspectives for theological education in Africa: legacy and new beginnings in Ecumenical Theological Education/World Council of Churches. Missionalia 38(2):275-293.

Werner, D 2009. Challenges and opportunities in theological education in the 21st century. ETE/WCC: Bossey Ecumenical Institute, Geneva.

Western, S 2008. Leadership: a critical text. London: Sage.

Wilton, G 2007. The Hind Report: theological education and cross sector partnerships. Discourse: Teaching and Learning in Philosophical and Religious Studies 7(1):153-178. 